\title{
Lifestyle Identity Construction of Celebgram on Instagram (Case Study of @AmeliaElle)
}

\author{
Dwitriani Ulfi Rifqiningsih ${ }^{1, *}$ Puspita Sari Sukardani ${ }^{2}$
}

\author{
${ }^{1,2}$ Universitas Negeri Surabaya, Indonesia \\ *Corresponding author.Email: dwitriani.17041184083@mhs.unesa.ac.id
}

\begin{abstract}
This study aims to find out how the process of forming the identity of the celebrity lifestyle is carried out by the celebrity (a) ameliaelle through their daily activities. The theory used in this study is the theory of identity constructionfrom J.M. Baldwin and the theory of lifestyle according to Kotler and Armstrong. The research approach used is a qualitative approach by looking at the phenomenology of new media and constructivists. The data analysis techniquein this study uses an interactive model analysis technique from Huberman and Miles. Data collection techniques werecarried out by means of observation and interviews. The informant in this study was Amelia as the celebgram owner of the Instagram account@amelialle. The results showed that Elle lifestyle as a celebrity got many followers and made Elle a lifestyle reference. They identity construction process is built through a social environment that is intentionally formed on his Instagram account, and the environment consists of his Instagram account, and the environment consist of his friends only. Then, the social environment as been formed, the self-concept of an Elle is built naturally by only doing her daily activities which are then uploaded on Instagram. Meanwhile, lifestyle is processed through internal factors, namely attitude as a goal to build the values that exist in him so as to produce a good image, experiences and observations are made because of repetition in his activities so as to produce an attractive impression among his Instagram followers, personality is formed through habits in carrying out dail activities. Self-concept in conveying messages is not shaped to be persuasive bu can generate Instagram followers, his motives are the messages conveyed, and perception produces an image as a celebrity. Further, suggestion for research are expected to understand the construction of identity in lifestyle.
\end{abstract}

Keywords: Identity construction, Lifestyle, Celebrity instagram.

\section{INTRODUCTION}

People`s dependence on gadgets and technology makes Indonesian people from various professions grow individual images by utilizing social media. For social and professional needs, account holds display their activity towards their interest in certain fields. Currently, many Instagram users have a large number of followers, this is because the way the account present itself on Instagram is considered unique and provides a good example for other account users. Accounts that are unique, by displaying lifestyle references are known as Celebgram or
Instagram Celebrities. Celebgram is a term for users of famous Instagram accounts on the social networking site. The term celebrity comes from the words celebrity and Instagram which can be understood as celebrities who are famous on Instagram. Basically a celebrity is someone who becomes the center of attention of others for what he does, so that person becomes interesting to follow, idolize, and become the center attention.

Likewise, with celebgrams, celebgrams become the center of attention because they are unique in their daily lives. The popularity of 
celebgrams is supported by their activities as advertising tarts in a brand (endorsement recipients) form advertising promotional activities for a product or service. The formation of the celebrity lifestyle is seen by the way he expresses his identity through uploading their content on his personal Instagram account. The unique identity that has been formed provides the opportunity for celebrities to take advantage of their uniqueness by accepting endorsements as a form of product promotion. Endorsement has now become one of the income for celebgram. Celebrities will set rates for the product promotion. Endorsement has now becoe one of the income for celebgram. Celebrities will set rates for the products they will promote. Through uploads to his personal Instagram account, it will attract followers to see or respond by buying the promoted product.

\section{METHODS}

According from the type pf data used in thisstudy is a qualitative approach. According to Bodgan quoted by Lexi J. Moleong [1], qualitative methodology is a research procedure that produces descriptive data in the form of written or spoken words from people and observed behavior. A qualitative approach is a method that is defined to understand a constriction of the identity of the celebrity's lifestyle on Instagram social media on the Instagram account of the celebrity @ Ameliaelle about what Ameliaelle has represented, for example lifestyle, perception, behavior, action, and others as a whole and by describing in the form of words and language.

Qualitative research is divide into a several typesof research that have been determined through a phenomenon with current developments. Qualitative research contained in this research is because in this study researcher will describe an object of study by explaining and understanding the essence of the experience of a phenomenon that occurs. In this study, namely an experience carried out by celebrities, especially the Ameliaelle celebrity in constructing themselves on the phenomenon of the celebrity lifestyle on Instagram.

\section{RESULTS AND DISCUSSION}

Amelia`s was created on her Instagram social media account $b$ having followings and followers who were deliberately formed by her. The social environment that Amelia deliberately created was initially only as a normal friendship on Instagram social media. Amelia didn't intentionally set up her Instagram account to have a large number of followers. Just a close friend, to share information through uploads on each Instagram account. However, to use social media Instagram is deliberately done by Amelia, like other individuals in general. From the beginning using this Instagram social media account, Amelia has also used it as it is now, by uploading her routine as content on Instagram. Uploading the routine has been done repeatedly until now, and there is no difference from the start using his Instagram account. According to

J.M Baldwin in Barker [2] the social environment is formed through four aspect of social construction. First "Self" refers to oneself and is an active and wellorganized initial concept. On this basis, the environment develops in accordance with the concept that has been formed so as to make the individual develop actively in the process of constructing identity in the social environment.

The environment is developed by following several Instagram accounts such as the Instagram account of a product or the Instagram account of an artist. To find references about her preferences, or to add a variety of views to her Instagram account, Amelia added her following by following several other Instagram accounts. With a pre-existing feature on Instagram accounts. With a pre-existing feature on Instagram, namely tags, Amelia uses this feature when uploading her Instagram content when using a product she likes. Of course, at the time Amelia did this, there was no request from anyone such as product promotion, but because Amelia did use the product to support her activities. The product is like clothing, or the concept of home decoration. According to J.M Baldwin in Barker [2] the social environment is formed through three aspects of social construction. Second, "self" does not exist when he isjust born and appears when he has begun to developin a certain environment. If the individual is for the first time the existing social environment, the concept to explain how the construction of identity is notdirectly created, it is necessary to do several ways asa strong supporting factor so that the concept can develop. The concept of identity construction also requires the description of other individuals as a reference for the development of their identityconstruction. 
That routines are uploaded make the formation of the social environment on Instagram develop continuously. There is nothing contrived that is deliberately used as content to be uploaded by Amelia. Everything that is displayed on Amelia's Instagram account provides an example that a routine can look interesting and has followers who always pay attention to their activities. Daily routines such wearing clothes during activities visiting places usingcertain product are Amelia's activities as she does. This has attracted the interest of many people, because from the start using social media Instagram has done things like that until now. According to J.M.Baldwin in Barker [2] the social environment is formed through three aspects of social construction. Third, "Self" is a certain product of the social environment. Describe the individuals as something interesting. It is said to be a product because it has its own fans so that there are those who imitate and follow it. If it is developed by itself that the environment, it is necessary to continue to carry out activities in order to maintain the value of the product.In a sense, if it is said to be a celebrity, it is necessaryt have a stable behavior in order to make a good impression on its followers, and relate, to its Instagram followers.

Amelia interacts with the social environment on her Instagram account. Until now, not only by following other Instagram accounts or other products to get references about certain things. Doing social interaction with the environment makes the individual continue to grow because it accommodates several existing point of view. Interaction also keeps the social environment conducive, there are no gaps that lead to bad judgements about individual. The comment column or direct massage feature is one way message interaction, besides being able to exchange ideas about certain concepts, Amelia`s Instagram followers will also feel that they are considered different. The interaction which is then displayed again through the upload of Instagram content, will become information for other Instagram followers. According to J.M. Baldwin in Barker [2] the social environment is formed through three aspects of social contrition. In place, "Self" is formed and stable as a result of interaction with the social environment. For example, if in the family environment, the social environment, occurs between father, mother, brother, sister, but if in the virtual world, interaction will occur by anyone and for any reason. Everything happened so fast and can openly strengthen the concept of each of them.
The social environment formed by Amelia on her Instagram account was deliberately shaped byherself so as to produce a big concept as a current celebgram. Starting from herself who likes to upload his daily routine as my Instagram content. This has unconsciously become a concept in building and displaying what is on Instagram page. After that, this method is carried out continuously and repeatedly by bringing the impact of the development of the social environment of the social environment to be so widespread. The increase in followers on the account shows the interest in identity construction, which is actually the same as what people usually do, but still looks interesting. The concept focuses on the way Amelia wears clothes, visits a place, according to existing developments. Social interaction is carried out by using the comment column and direct massage features for him to ger additional references to upload information to followers on his Instagram account. @)Ameliaelle Instagram account has an interest in followers towards Amelia by seeing the simplicity of her sharing her daily routine. Built through uploads with clothes that are being used in their daily activities. Not only that activities such as vacation when visiting a place also don't escape to capture the moment which is then uploaded to his Instagram account. With the interest among followers of Amelia, it shows that the self- concept built by her goes well in the process of constructing personal identity. This illustrates the belief about Amelia's existence according to other individuals.

A basic example of the recognition of Amelia's activities as a celebrity is when asked to promote a product, or asked about a fashion product that is being used by Amelia. The concept of Amelia`s Instagram page also looks attractive with the selection of neatly arranged design to pamper other accounts that visit Amelia's Instagram account page. Interest in Amelia`s Instagram account does not only come from personal accounts, but several MSME in the fashion sector follow a lot for endorsement purposes. According to J.M Baldwin in Barker [2] Self concept cannot be separated from the feeling of a person's attitude towards himself. Feelings, perceptions, beliefs appear as a form of recognition of the existence of Amelia's identity. Recognition of Amelia's existence as a celebgram is evidenced by herself as a celebgram who can persuade about her life to reference the activities of other individuals through activities. 
Amelia`s predicate is currently dubbed as a fashion and lifestyle celebrity. Fashion and lifestyle are attached to Amelia because she uploads contentby displaying the clothes she uses. Not only that, it turns out that entrepreneurs in the field of fashion, hijab, do endorsements to promote the products to be sold. Sometimes, without being endorsed by a product Amelia still uploads about the brand that is used to be informed to her Instagram accountfollowers.

The actual information is not widely requested by followers, but it turns out that in this way Amelia has become a celebgram to this day. This humble attitude can provide followers with various kinds of information about the ideal fashion and lifestyle needs to use. Amelia's activities made her a celebgram, not because she wanted to be a celebgram. Because she like to uploadcontent in the form of information about fashion and lifestyle because of her routine and accidentally made Amelia a celebrity. According J.M Baldwin in Barker: [2] self-concept creates the quality of an individual character about himself. These attributes are described by other individuals about Amelia, the described with the meaning of each individual.

The attitude of followers makes Amelia a reference form fashion to lifestyle. This attitude is formed by the existence of a social media environment that continues to grow and supports Amelia's activities. Apparently, the supports provide by Instagram followers@Ameliaelle is one way keep followers getting references in fashion and lifestyle. No party is harmed in this case, because Amelia is very happy when the request for content is the same as what she really likes to upload, especially fashion and lifestyle are routines that Amelia always does. According to J.M Baldiwin in Barker [2] talking about self-concept is a system of meaning for individuals and the views of others about themselves. In this case, followers interpret Amelia as a celebgram that can represent references in fashion and lifestyle to their Instagram followers. According to J.M Baldwin in Barker [2] self-concept is formed through one's perception, beliefs feelings, and formed through one's perceptions, beliefs, feelings, and attitudes about a particular individual. In addition, she also argues that the characterization of herself is formed by himself and is given by other individuals, so that can interpret the views of Amelia.
The usual fashion lifestyle looks like it always looks modern. Related to this discussion, there is the firsy concept, namely according to J.M Baldwin in Barker [2] the image that is displayed byshowing the attractiveness of his body. The image displayed bye Amelia on her Instagram account has its own charm form her followers. Namely, Amelia's beauty is shown with a good image, through her appearance which is still fashionable, contemporary, and hasgood manners.

The fashion used always looks consumerate, with a calm demeanor that creates an elegantimpression from the image that has been created. Wrapped in hijab fashion, adding to the appearance of courtesy while still being able to look modern or contemporary. Her beauty is much appreciated when these followers make herself a fashion and lifestyle recommendation. Seen many who want to follow to keep appearing with today`s style. In addition, even with the hijab Amelia also continues to carry outoutdoor activities by prioritizing the side of good manners. When the lifestyle is shown during holidaysto beach, Amelia still looks fashionable by using the hijab and looks more attractive than the individuals around her. This method is used by women who use the hijab as a dress reference to keep appearing today.Information about fashion and lifestyle is hared via Instagram uploads.

Instagram is used by Amelia as a means to convey information, in addition to using it to capture moments of ger routine. The second component, according to J.M Baldwind in Barker [2] in the self-concept is the ability (excellence of herself) and inability (weakness) of each individual. The advantage that Amelia can do in constructing identity is that she can in advedtaly persuade many people to become followers of her Instagram account. In addition, the next advantage is that it can be accepted by the Instagram social media environment, Amelia's acceptance in Instagram is evidenced by the questions given by followers to answer concern in choosing the fashion to be used. These followers trustAmelia to provide references about fashion and lifestyle. Trust is also given by business actors by using@Ameliaelle as a way to promote product by implementing an endorsement system. The business actor's trust arose because Amelia on her way to using Instagram could persuade people unintentionally so that she got a relative large numberof followers. 


\section{CONCLUSION}

Based on the results of research conducted by researchers do through an interview with Amelia as informants, the researcher then answeredidentification. The problem that the researcher has setis "How is the process of forming a style identity celebgram life done by @Ameliaelle through activityon Instagram?" and has been a researcher describe the answer to the identification of the problem on thesheet of research results and discussion. So, the conclusion of this researcher is the social environment can affect individual identity, becausesocial environment will have a direct impact to eachindividual. Influence from environment can beformed by itself, unconsciously, and it happens continuously. Interaction in the social environment is one of the factors that cause theimpact and influence felt by each individual.Every individual must interact with the environmentevery day, happens naturally intentionally orunintentionally. Self-concept is the model shown by an individual to other individuals, thus giving rise tothe perception of others to the individual. Thatperception can be in the form of appreciation for themodel shown by individuals if it looks attractive orhas advantages and can also be a criticism if not there is compatibility with other individuals. Construction Identity is a behavior that is indicated by judgments from other individuals.

\section{REFERENCES}

[1] L. J. Moleong, Metode Penelitian Kualitatif, Bandung: Remaja Rosdakarya, 2009.

[2] C. Barker and E. A. Jane, Cultural Studies: Theory and Practice., London: SAGE Publication Ltd, 2016. 